\title{
UKRAIŃSKA FILOLOGIA NA UNIWERSYTECIE LWOWSKIM W XIX WIEKU I W PIERWSZEJ POŁOWIE XX STULECIA. LUDZIE, IDEE, RECEPCJE
}

\author{
Roman Holyk \\ Instytut Ukrainoznawstwa im. I. Krypiakewycza NAN Ukrainy we Lwowie
}

\author{
ABSTRACT \\ THE UKRAINIAN PHILOLOGY AT THE LVIV UNIVERSITY IN THE \\ NINETEENTH AND FIRST HALF OF TWENTIETH CENTURY. PEOPLE, \\ IDEAS AND RECEPTION
}

The author analyzes the formation and evolution of Ukrainian Philology at the Lviv University from 1848 to 1939. In the context of this article, the history of Ukrainian philological studies is represented through such personalities as Yakov Holovatsky, Omelyan Ogonovsky, Alexander Kolessa, Ilarion Sventsitsky, Cyril Studinsky and Jan Janów. Part of them symbolizes the theological or clerical period of the development of the Ruthenian (Ukrainian) philology in Galicia, the other part demonstrates the secularization of the Ukrainian humanities as well as the intellectuals themselves. The evolution of the Ukrainian studies at the Lviv University is a history of changing scientific paradigms: from post-romanticism to factographism and positivism or critical rationalism. The study also demonstrates the growth of the interrelation between the Ukrainian philologists on the Lviv and Kraków (Jagiellonian) University in the examined period. The history of Ukrainian Philology in Lviv is a history of ideological evolution and/or ideological hesitation in the Ukrainian intelligentsia between Ukrainophilism, Russophilism, political neutrality, Polonophilism and Austrophilism. It is also the result of the "tolerance within confrontation" - the ethno-social competition, struggle and compromise between the Ukrainian and Polish ideas in Galicia. In other words, it is a history of the Ukrainian intelligentsia and Ukrainian society in Lviv and in Galicia before the Second World War.

Key words: Ukrainian philology, Galicia, history, University of Lviv, Yakiv Holovatsky, Omelyan Ogonovsky, Alexander Kolessa, Ilarion Sventsitsky, Cyril Studinsky, Jan Janów.

Słowa kluczowe: filologia ukraińska, Galicja, historia, uniwersytet we Lwowie, Jakiw Hołowackyj, Omelian Ogonowskyj, Ołeksandr Kołessa, Ilarion Świencickyj, Kyryło Studyńskyj, Jan Janów. 
W ostatnich latach uniwersytet we Lwowie cieszy się coraz większym zainteresowaniem naukowców. $Z$ jednej strony skłaniają do tego daty jubileuszowe związane z uczelnią, zwłaszcza 350. rocznica jej założenia, obchodzona w 2011 roku, z drugiej postrzeganie Lwowa jako miasta mitycznego (zarówno w kulturze i literaturze polskiej, jak i ukraińskiej). Podobnie jak w przypadku Lwowa w wiekach XIX i XX (jako miasta „austriackiego” w latach 1772-1918, polskiego - w latach 1918-1939 i ukraińskiego po 1939 r.), mamy do czynienia z co najmniej kilkoma odrębnymi recepcjami uczelni: jako austriackiej wszechnicy Franciszka I (1817-1918), polskiego Uniwersytetu Jana Kazimierza we Lwowie (1919-1939) oraz ukraińskiego Uniwersytetu Iwana Franki po 1939 roku. Ta złożona specyfika funkcjonowania i postrzegania uczelni, nie do końca przecież słuszna, wciąż budzi kontrowersje nawet wśród badaczy: Ukraińcy postrzegają lwowski uniwersytet z punktu widzenia ukraińskości Lwowa, Polaków interesuje przede wszystkim polski element kultury miasta i polskie tradycje uczelni ${ }^{1}$ (oczywiście nie zawsze ta opinia znajduje potwierdzenie w badaniach poszczególnych uczonych). W niniejszym artykule chciałbym się skupić wyłącznie na postaciach związanych z rozwojem uniwersyteckiej ukrainistyki w XIX stuleciu oraz w pierwszej połowie XX wieku, na ich karierze naukowej, spuściźnie intelektualnej oraz odbiorze społecznym.

Już pod koniec XVIII wieku we Lwowie pojawił się problem „katedr ruskich” (tj. katedr z ruskimi/ukraińskimi wykładowcami oraz ruskim językiem nauczania). Przez cały wiek XIX kwestia języka wykładowego miała nie tyle filologiczne, ile polityczne znaczenie. Chodziło o społeczną rywalizację języka ruskiego (ukraińskiego) oraz cerkiewnosłowiańskiego z językami polskim, niemieckim i łacińskim. Rusini (Ukraińcy) dążyli do obsadzenia różnych katedr uczonymi prowadzącymi wykłady w ich języku, gdyż jeszcze w latach 80. XIX wieku mieli tylko katedrę teologii pastoralnej, katedrę prawa austriackiego oraz - najważniejszą - katedrę języka i literatury ruskiej. Ta ostatnia, jak pisał Omeljan Ogonowski, była w 1848 roku odbierana jako przykład dbania rządu austriackiego o rozwój i awans społeczny ukraińskiej wspólnoty w Galicji: „Rząd austriacki dowiedział się, że ruskie wykłady na uniwersytecie tylko wtedy mogą być pożyteczne dla naszego narodu, kiedy będzie położony niepodważalny fundament dla zasadniczego rozwoju języka ruskiego. Dlatego pomyślał on już w 1848 r. najpierw wprowadzić katedrę języka i literatury ruskiej, a potem zaprowadzić inne katedry na lwowskim uniwersytecie"².

1 Zob: Encyclopedia. Львівський національний університет імені Івана Франка, 2 т., Львів 2011; Akademia militans. Uniwersytet Jana Kazimierza we Lwowie, red. A. Redzik, Krakow 2015; Universitati Leopoliensi. Trecentesimum quinquagesimum anniversarium suae fundationis celebranti. In memoriam. Uniwersytetowi Lwowskiemu dla upamiętnienia trzysta pięćdziesiątej rocznicy jego fundacji. Materiaty sesji zorganizowanej w dniach 14-15 stycznia 2011 w Krakowie przez Uniwersytet Jagielloński, Wyższa Szkołe Filozoficzno-Pedagogiczna „Ignatianum” w Krakowie, Uniwersytet Papieski Jana Pawła II w Krakowie, Polska Akademię Umiejętności, Kraków 2011; Р. Голик, Alma Mater Leороlitana: Львівський університет в уявленнях галицької інтелігенції ХІХ-ХХ ст., „Вісник Львівського університету. Серія історична" 2013, Вип. 49, s. 78-92; О. Сухий, Львівський університет на рубежі XIX-XX ст.: організачія, школи, громадське життя, „Вісник Львівського університету. Серія історична" 2013, Вип. 49, s. 52-77.

2 О. Огоновскій, Исторія литературы рускои, Львів 1889, Часть II, І відділ, s. 58-59. 
Korzeni ukraińskiej filologii we Lwowie można szukać w różnych środowiskach³. Założenie katedry języka i literatury ruskiej było natomiast bezpośrednio związane z postacią Jakiwa Hołowackiego. Urodzony 17 października 1814 roku we wsi Czepeli (powiat brodzki), w rodzinie kapłana greckokatolickiego Jakiwa Hołowackyja (pol. Jakub Hołowacki lub Hłowacki, ros. Яков Федорович Головацкій), stał się wybitną, a jednocześnie kontrowersyjną postacią ruskiego (ukraińskiego) ruchu narodowego połowy XIX wieku4. W 1831 roku jako absolwent lwowskiego gimnazjum dominikańskiego został studentem Wydziału Filozoficznego uniwersytetu lwowskiego. Już wówczas formował własne wyobrażenie, czym ma być „filologja ruska”. W ówczesnym rozumieniu tego pojęcia nie było jednomyślności. W czasie nauki gimnazjalnej Hołowackiego za studiowanie języka ruskiego uważano głównie umiejętność czytania tekstów cerkiewnosłowiańskich. Sam Hołowacki początkowo notował pieśni ukraińskie w polskiej lub łacińskiej transkrypcji i posługiwał się w komunikacji codziennej raczej polszczyzną niż językiem ruskim (ukraińskim) ${ }^{5}$. Dopiero dzięki znajomości z Markijanem Szaszkiewiczem oraz Iwanem Wahylewiczem podczas studiów uniwersyteckich wykrystalizowało się jego wyobrażenie o „ruskości”. Pod wpływem pierwszego z nich zaczął posługiwać się prawie wyłącznie ruskim (ukraińskim) językiem (naturalnie w jego postaci zachodnioukraińskiej). Hołowackiego, Szaszkiewicza i Wahylewicza za świadome pielęgnowanie języka w życiu codziennym nazwano później „Ruską Trójcą” (grupa o takiej nazwie powstała w 1832 r.; była to organizacja społeczna i kulturalna licząca kilkudziesięciu członków, z których najważniejszymi byli trzej wymienieni). To początkowo humorystyczne określenie, jakim wyróżniano trzech lwowskich studentów na językowo polskim i niemieckim tle uniwersyteckim, po latach stało się klasycznym określeniem ideologicznego środowiska ukraińskich „,budzicieli” (na wzór czeskich buditeluv) ${ }^{6}$. Właśnie w tym kręgu wyrosła i została zrealizowana idea „Rusałki Dnistrowej” (1837) - pierwszego almanachu w fonetycznej pisowni i języku zbliżonym do języka ludowego (w zachodnioukraińskiej formie gwarowej). Na jego łamach Jakiw Hołowacki (występujący pod słowiańskim imieniem Jarosław) prezentował się jako folklorysta oraz wydawca dawnych cyrylickich pamiątek rękopiśmiennych. Mimo że „Rusałka” nie została dopuszczona do druku przez cenzurę, jej nakład częściowo zniszczono po wydaniu na Węgrzech, a jej autorzy nie cieszyli się zaufaniem władz kościelnych i państwowych, dalsze losy Hołowackiego przez pewien czas układały się dość pomyślnie. Jako absolwent teologii od roku 1841 pełnił on funkcje „sotrudnyka” oraz parocha (proboszcza) we wsiach galicyjskich (jak Mykytynci, Chmeliewa). Przy tym

3 Н. Хобзей, 3 історії львівської діалектології [w:] Діалектологічні студї̈, 4: Школи, постаmi, проблеми, Львів 2004, s. 63-72.

4 Zob. szerzej: J. Kozik, Ukraiński ruch narodowy w Galicji w latach 1830-1848, Kraków 1973; idem, Między reakcja a rewolucją. Studia z dziejów ukraińskiego ruchu narodowego w Galicji w latach 1848-1849, Kraków 1975.

5 О. Огонов в кій, op. cit., Часть IV, s. 60-150; W. Osadczy, Święta Ruś. Rozwój i oddziaływanie idei prawosławia w Galicji, Lublin 2007, s. 135-160.

${ }_{6}$ Zob. szerzej: W. Mokry, Ruska Trójca. Karta z dziejów życia literackiego Ukraińców w Galicji w pierwszej polowie XIX wieku, Kraków 1997. 
dalej prowadził studia naukowe z zakresu folklorystyki, etnografii, języka, literatury oraz historii ukraińskiej. W tym czasie opublikował między innymi dwutomowy almanach „Вінок русинам на обжинки” (Wiedeń 1846-1847), a także artykuły etnologiczno-folklorystyczne i historyczne, zmieszczane w „Časopis českého Museum” $(1841,1843)$ oraz „Zeitschrift für slavische Literatur” (1844). W 1848 roku, podczas „Wiosny Ludów”, Hołowacki wystąpił na pierwszym ruskim zjeździe oświatowym, tak zwanym soborze uczonych ruskich (Собор руських вчених) we Lwowie z „Rozprawą o języku ruskim i jego gwarach". To wystąpienie wysunęło Hołowackiego na jedno z czołowych miejsc wśród ówczesnej rusko-ukraińskiej inteligencji w Galicji. Co więcej, wygłoszone przez niego tezy zostały przez potomnych uznane za program jedności i odrębności narodu ruskiego (małoruskiego), jego języka i kultury, nie tylko w granicach Galicji czy Bukowiny, ale także w Imperium Rosyjskim.

Nie ma się zatem co dziwić, że kiedy zapadła decyzja o utworzeniu katedry języka i literatury ruskiej na uniwersytecie lwowskim, Jakiw Hołowacki był uważany za najbardziej odpowiedniego kandydata. Aktywnie wspierany przez takich działaczy jak Dionizy Zubrycki oraz Michał Malinowski z archikatedry św. Jura, Hołowacki zdecydował się objąć katedrę, rezygnując jednocześnie z prezenty na parafię, która mu była w tym samym czasie także ofiarowywana. Już we wstępnych wykładach uniwersyteckich Hołowacki nakreślił strategiczne cele swoich zajęć oraz wizje literackiego i językowego rozwoju narodu ruskiego (ukraińskiego). Widział go w perspektywie trzech głównych okresów: samodzielnego politycznego istnienia w czasach ruskich książąt, w dobie „polsko-litewskiej” i w nowych, współczesnych mu warunkach dziejowych. W takim ujęciu ,język i literatura ruska” oznaczały ,język i kulturę ukraińską (małoruską)", obejmującą tereny ówcześnie należące do Austro-Wegier oraz zazbruczańskie ziemie Imperium Rosyjskiego, zamieszkiwane przez „Rusinów”/„Małorusów” (czyli Ukraińców). Taką koncepcję prezentowała również jego Gramatyka języka ruskiego (Граматика руского язика, 1849), oparta na galicyjskich gwarach ukraińskich, które dla Jakiwa Hołowackiego stanowiły wzorzec „ruskiego języka ludowego”. Na podstawie tej koncepcji realizował dalsze projekty wydawnicze?

Jednocześnie po 1850 roku Hołowacki coraz bardziej interesował się językiem cerkiewnosłowiańskim, a także językiem rosyjskim („великорусским”) i literaturą w tym języku. Tego drugiego coraz częściej używał jako „ruskiego” w swoich wykładach $^{8}$. Już na początku lat 60. XIX wieku uchodził za zwolennika panruskiej („общерусской”) ideologii, którą w różny sposób starał się rozpowszechniać wśród słuchaczy uniwersyteckich. Jednocześnie jako ksiądz/teolog został zdecydowanym przeciwnikiem wszelkich przejawów latynizacji obrządku greckokatolickiego, a jako filolog sprzeciwiał się latynizacji graficznej języka ruskiego (ukraińskiego) w Galicji. Próby używania alfabetu łacińskiego w języku ruskim uważał za przejawy ukrytej polonizacji Rusi Halickiej; sam zmierzał ku jej ideologicznemu i kulturowemu

О. Седляр. Важливі епізоди історії книговидання галиџьких русинів 40-50-х років ХІХ ст. (видавнича діяльність Якова Головачького) [w:] Studia o ksiażce i informacji, red. M. Komza, Wrocław 2014, nr 33 (Acta Universitatis Wratislaviensis, nr 3653), s. 61-75.

8 М. Мозер, Причинки до історії украӥнської мови, Харків 2008, s. 603-626. 
połączeniu z Małą, Wielką i Białą Rusią. W podręczniku dawnej literatury ruskiej, który pisał w tych latach, umieścił więc liczne dzieła autorów „północnowschodnich", którzy reprezentowali państwo moskiewskie. Tym samym Hołowacki został propagatorem rosyjskiej literatury w Galicji'.

Z jednej strony kariera naukowa Hołowackiego we Lwowie rozwijała się pomyślnie (w roku akademickim 1863/1864 pełnił nawet funkcję rektora uniwersytetu), z drugiej jednak strony już w latach 50. XIX wieku coraz wyraźniej zarysowywał się groźny konflikt między Hołowackim i jego głównym rywalem politycznym Agenorem Gołuchowskim. Ten ostatni, gdy został namiestnikiem Galicji, przedstawiał działalność uczonego i jego sprzymierzeńców przed władzami w Wiedniu jako ukrytą realizację projektu oderwania Galicji od Austro-Węgier i przyłączenia jej do Imperium Rosyjskiego. Sugerował zatem usunięcie Hołowackiego z katedry, żeby zneutralizować jego rzekomy wpływ na studentów, wśród których nie brakowało kleryków greckokatolickiego seminarium duchownego. Próby rehabilitacji nie przyniosły uczonemu zadośćuczynienia. Został zawieszony w prawach profesora i ostatecznie w 1867 roku wyemigrował do Imperium Rosyjskiego, przechodząc na prawosławie. Nie zaprzestał jednak pracy naukowej. W Rosji zostało wydane jego fundamentalne trzytomowe dzieło Народныя песни Галиикой и Угорской Руси (Pieśni ludowe Rusi Halickiej i Węgierskiej, 1878), uznane za jedną z podstaw folklorystyki ukraińskiej XIX wieku. Otrzymał za tę pracę złoty pierścień z rubinami i brylantami oraz Nagrodę Uwarowowską z gratyfikacją 500 rubli. We Lwowie wśród inteligencji ukraińskiej i polskiej był uznawany za wybitnego uczonego, który jednak odszedł od poglądów Szaszkiewicza; niekiedy wprost określano go jako apostatę religijnego i politycznego. Tylko galicyjscy rusofile (moskalofile) całkowicie popierali jego postawę, uważając go za czołowego przedstawiciela „karpato-ruskiej” czy „galicyjsko-ruskiej” literatury, nauki i myśli społecznej. Jako postać wzbudzająca sprzeczne opinie zmarł 13 maja 1888 roku w Wilnie.

Następcą Hołowackiego na katedrze we Lwowie został Omelian (Emilian, Emil) Ogonowskyj (Ogonowski). Reprezentował nie tylko zupełnie inny ideologiczny kierunek, ale też inny paradygmat naukowy ${ }^{10}$. Urodzony 3 sierpnia 1833 roku we wsi Grygorów w powiecie stryjskim ${ }^{11}$, w rodzinie księdza greckokatolickiego, po ukończeniu gimnazjów w Brzeżanach i we Lwowie studiował w greckokatolickim seminarium duchownym we Lwowie i był słuchaczem wykładów filologicznych na uniwersytecie lwowskim. Potem uczył religii w II Gimnazjum we Lwowie oraz języka ruskiego (ukraińskiego) w tamtejszym Gimnazjum Akademickim. W 1865 roku

9 О. Седляр, Хрестоматія руської літератури Якова Головацького як інформаиійний та освітній проект: плани та їх реалізація, „Вісник Львівського університету. Серія книгознавство, бібліотекознавство та інформаційні технологіі” 2012, Вип. 7, s. 19-53: А. В. Седляр, Яков Головаикий и поступление российских изданий в Галицию (1848-1867 г2.) [w:] Берковские чтения. Книжная культура в контексте международных контактов: материаль Междунар. науч. конф., Минск, 16-17 мая 2013, ред. Н. Ю. Березкина, В. И. В асильев Минск 2013, s. 337-340.

10 І. Кокорудз, Професор др. Омелян Огоновский. Огляд єго житя і наукової та літературної діяльности, „Записки Наукового Товариства імені Шевченка” [dalej: ЗНТШ], 1895, т. 5, s. 1-34.

11 В. Пашук, Огоновський Омелян Михайлович [w:] Енииклопедія історії України у 10 mm, т. 7, Київ 2010, s. 523. 
doktoryzował się na podstawie rozprawy „Über der Praepositionen in der altslovenischen und ruthenischen Sprachen", napisanej według założeń popularnej później szkoły młodogramatycznej, z akcentem na studia językowo-komparatystyczne. Ze względu na fakt, że wówczas w środowisku lipskich językoznawców szkoła ta dopiero się kształtowała, jego pracę należy uznać za nowatorską. Ogonowski inspirował się głównie pracami wiedeńskiego uczonego Franza Xawera Miklošiča z zakresu slawistyki porównawczej oraz lwowskiego badacza Antoniego Małeckiego z zakresu języka polskiego. Obaj językoznawcy pozytywnie ocenili rozprawę doktorską Ogonowskiego. W 1867 roku, po wyjeździe Jakiwa Hołowackiego do Rosji, Ogonowski został zastępcą profesora, a w 1870 roku profesorem języka i literatury ruskiej na uniwersytecie lwowskim. W tym czasie starał się pogłębiać kontakty z głównymi szkołami językoznawczymi na świecie: Franza Miklošiča (Wiedeń) oraz Friedricha Müllera (Wiedeń), a także Augusta Friedricha Potta (Halle).

Głównym przedmiotem badań Ogonowskiego pozostała lingwistyka historyczna i komparatystyczna. Potwierdzają to jego podręcznik języka staro-cerkiewno-słowiańskiego (Linguae palaeslovenicae specimina, Lwów 1871) oraz obszerne artykuły w krakowskich „Rozprawach i Sprawozdaniach z Posiedzeń Wydziału Filologicznego Akademii Umiejętności”, poświęcone etymologii i funkcji gramatycznej przyimków w językach słowiańskich (O przyimkach w języku starosłowiańskim, ruskim i polskim) oraz miejscu języka ruskiego (ukraińskiego) w ogólnosłowiańskim kontekście ( $O$ ważniejszych właściwościach języka ruskiego), a także polonistyczne studium językowe na temat Biblii Królowej Zofii w „Archiv für slavische Philologie" (Einige Bemerkungen über die Sprache der altpolnischen Sophia Bibel, $1880)^{12}$. Syntetyczna monografia Ogonowskiego Studien auf dem Gebiete der rutenischen Sprache (Lemberg 1880) była natomiast w całości skoncentrowana wokół fonetycznej, etymologicznej, leksykologicznej oraz składniowej analizy języka ukraińskiego, jego historii i dialektologii na tle porównawczym. Głównym celem pracy, jak to określał autor i odbierali ówcześni czytelnicy, było uwypuklenie zasadniczych cech lingwistycznych języka ruskiego (ukraińskiego) i, co ważniejsze, ukazanie ,jego odrębności od wielkoruskiego i samodzielności między innymi językami słowiańskimi"’13. Inne dzieło uczonego o tej tematyce, szkolna gramatyka języka ukraińskiego pod tytułem Граматика руского языка для школъ середнихъ (Lwów 1889), miało pedagogiczno-dydaktyczny i praktyczny charakter. Stało się ono na dłuższy czas oryginalnym ekwiwalentem wielokrotnie wznawianej szkolnej gramatyki języka polskiego Antoniego Małeckiego, a nawet przeciwwagą dla niej. Studia i wykłady lingwistyczne uważał Ogonowski za główny kierunek swojej działalności profesorskiej. We wspomnieniach jawi się jako człowiek dążący do wyraźnego odseparowania się od studiów literackich, które miał nawet lekceważyć. Przypisywano

12 E. Ogonowski, O przyimkach w języku starostowiańskim, ruskim i polskim, „Rozprawy i Sprawozdania z Posiedzeń Wydziału Filologicznego Akademii Umiejetności” 1877, t. 5, s. 17-222; idem, O ważniejszych właściwościach języka ruskiego, „Rozprawy i Sprawozdania z Posiedzeń Wydzialu Filologicznego Akademii Umiejętności” 1884, t. 10, s. 30-93.

13 І. Кокорудз, op. cit., s. 20 (tłum. z ukraińskiego na polski - autor. Podobnie w dalszej części pracy). 
mu wielokrotnie cytowane słowa: „Literatura - to babskie gadanie, a gramatyka - to grunt!”.

Studia nad historią literatury zostały jednak uznane za najważniejszą część jego spuścizny naukowej i literackiej. Eksponuje się zwłaszcza wielotomową, chociaż niedokończoną historię literatury ukraińskiej (Істория літератури рускої), którą zaczął wydawać częściami od 1886 roku w czasopiśmie „Зоря” oraz w oddzielnych tomach. Dzieło to łączyło teksty o literaturze pięknej z badaniami z zakresu etnografii oraz folklorystyki (też włączonych do kategorii „literackich”). Sformułował w nim kanon literatury ukraińskiej (w ujęciu działaczy ukraińskiego ruchu narodowego, tak zwanych narodowców): od ustnych źródeł dyskursu literackiego i latopisu Nestora przez Kotlarewskiego, Szewczenkę i Szaszkiewicza aż do pisarzy współczesnych Ogonowskiemu. Częściowym dodatkiem do tej syntetycznej historii literatury była także Хрестоматія староруска (Wypisy staroruskie, 1881) - wybór tekstów literatury staroukraińskiej dla uczniów szkół podstawowych i średnich. Książka ta miała usunąc wpływy podręcznika Hołowackiego, w którym dostrzegano zbytnie tendencje rusofilskie.

Historia literatury ukraińskiej w ujęciu Ogonowskiego to przede wszystkim faktografia. Czytelnik w obu pracach mógł znaleźć nie tylko analizy poszczególnych utworów, ale także dokładne biogramy (w tym i J. Hołowackiego). Autor skreślił je na podstawie materiałów historycznych oraz autobiografii pisarzy końca XIX wieku, które na życzenie Ogonowskiego przesyłali mu sami zainteresowani. Jego prace stały się zatem syntetycznym źródłem faktów o autorach i tekstach dawnej i nowej literatury ukraińskiej, a w dziale etnograficznym - zbiorem etnokulturowych mitów (charakterystyk etnopsychologicznych) i stereotypowych wyobrażeń o Rusinach-Ukraińcach, Polakach i Rosjanach. Swoje charakterystyki literackie i etnopsychologiczne Ogonowski rozpowszechniał także w popularnonaukowych wydaniach towarzystwa Proświta, jako jeden z jego głównych działaczy - w opozycji zarówno do rusofilskiego Towarzystwa im. Michała Kaczkowskiego, jak i polskiego Towarzystwa Szkoły Ludowej. Prace Ogonowskiego były krytykowane przez te organizacje.

Jednym z powodów zaostrzenia tej krytyki była postawa uczonego wobec kwestii języka ukraińskiego na uniwersytecie lwowskim. Ogonowski stanowczo domagał się poszerzenia wykładów $\mathrm{w}$ tym języku ${ }^{14}$. Z polskiej strony odbierano to jako próbę ukrainizacji polskiego $\mathrm{w}$ zasadzie uniwersytetu i sprzeciwiano się ukrainizacyjnym projektom wykładowcy. Jak pisano: „Tylko ks. prof. Emilian Ogonowski żądał, aby albo pozostawiono ówczesny stan rzeczy, albo też wprowadzono, dla zasady równouprawnienia, podwójny język urzędowy, polski i ruski; wniosek ten jednak nie uzyskał poparcia"15. Sam Ogonowski uważał siebie za spadkobiercę, ale równocześnie antagonistę Hołowackiego na katedrze uniwersyteckiej. $\mathrm{Z}$ jednej strony podkreślał pozytywną rolę swego poprzednika jako wykładowcy, z drugiej - stanowczo odrzucał jego rusofilizm oraz „oschłą i nieciekawą” manierę czytania wykładów w języku

14 Jego własny wykład inaguracyjny przez długi czas był uważany za jedyny przykład wykorzystania języka ukraińskiego w walce politycznej o utworzenie nowych katedr z ukraińskim językiem wykładowym.

15 L. Finkel, S. Starzyński, Historia Uniwersytetu Lwowskiego, Lwów 1894, cz. 2, s. 64. 
pseudorosyjskim. Samego Ogonowskiego jako wykładowcę uniwersytetu odbierano niejednoznacznie. Część słuchaczy uważała go za świetnego oratora, który przyciągał studentów erudycją - wspominali go jako wzorcowego pedagoga: skrupulatnego, pełnego taktu i tolerancyjnego, zawsze opierającego się na faktach, a nie na spekulacji teoretycznej. Tak zapamiętał go Illja Kokorudz, późniejszy dyrektor Gimnazjum Akademickiego we Lwowie:

Wykłady prowadził z pamięci przy pomocy skryptów, a mówił powoli, jasno i wyraźnie, przy tym tak czystym językiem i kwiecistym stylem, że przykuwał uwagę słuchaczy [...]. Nie dziw, że przynajmniej za moich czasów studenckich sala była pełna słuchaczy [...]. Była jeszcze jedna przyczyna, dlaczego liczba jego studentów była wielka - jego bardzo częste przyjazne i sympatyczne zachowanie wobec słuchaczy. [...] starał się naukę ruskiego podnieść na wysoki poziom powagi i znaczenia. Dlatego w wykładach podawał wprawdzie dużo materiału, sporo detali, ale podawał tylko to, co było pewne i prawdziwe, nie zaplątując się w dalekie teorie i hipotezy ${ }^{16}$.

Inny student Ogonowskiego, Iwan Franko, nie był natomiast zachwycony stylem i metodą profesora, które ten wykorzystywał w pracach $\mathrm{z}$ historii literatury ukraińskiej; uważał je za przestarzałe i zbyt faktograficzne ${ }^{17}$. Według Franki uczony pozostawał „kompilatorem [...] oraz popularyzatorem wszystkich dostępnych wiadomości bio- i bibliograficznych"18. Franko cenił natomiast językoznawcze prace Ogonowskiego - uważał je za główne osiągnięcie profesora, człowieka skrupulatnego, a nawet wręcz pedantycznego.

Nagła śmierć Ogonowskiego 28 października 1894 roku zaskoczyła wszystkich. Symbolizowała ona koniec procesu formowania się ukrainistyki jako dyscypliny na uniwersytecie lwowskim. Był to proces złożony zarówno pod względem ideologicznym, jak i metodologicznym. W latach 1848-1894 lwowska ukrainistyka uniwersytecka przeszła ewolucję ideowo-polityczną - od idei ruskiej czy staroruskej przez rusofilską (panrusyzm i panslawizm) aż po ideę ukrainofilską (narodową). Uczeni zmieniali też swoje metody badawcze - rezygnowali z romantycznego zachwytu nad folklorem z elementami historyzmu na rzecz krytycznego, pozytywistycznego podejścia i wręcz kultu faktów. Jednocześnie Jakiw Hołowacki i Omeljan Ogonowski byli księżmi greckokatolickimi, co na tym etapie oznaczało łączność teologii i filologii ruskiej (ukraińskiej) ${ }^{19}$.

Dalsze losy uniwersyteckich studiów ukrainistycznych we Lwowie łączyły się już z osobami świeckimi. Absolwentem uniwersytetu lwowskiego, który uzyskał doktorat $\mathrm{u}$ światowej sławy slawisty wiedeńskiego Vatroslava Jagića, był Iwan Franko (1856-1916). Jeden z najwybitniejszych pisarzy i uczonych ukraińskich w 1895

16 І. Кокорудз, оp. cit., s. 4.

17 Іван Франко. Документи і матеріали. 1856-1965, Київ 1966, s. 30, 36, 70-71, 81.

18 І. Франко, Професор Омелян Огоновський [w:] І. Франко, Зібрання творів: у 50 m., Київ 1986, т. 43, s. 381; В. Микитюк, Іван Франко та Омелян Огоновський: мовчання і діалог, Львів 2000.

19 O środowisku ukraińskich duchownych w czasach O. Ogonowskiego: Н. Колб, „3 Богом за Церкву і вітчизну”: греко-католищьке парафіяльне духовенство в Галичині в 90-х роках XIX століття, Жовква 2014. 
roku wydawał się idealnym kandydatem do objęcia docentury z języka i literatury ruskiej. Jego wykład habilitacyjny „Analiza Najmyczky Tarasa Szewczenki” zyskał uznanie profesorów Ludwika Ćwiklińskiego oraz Tadeusza Wojciechowskiego, a także studentów-Ukraińców ${ }^{20}$. Habilitant opracował także szczegółowy, bardzo nowatorski jak na owe czasy plan wykładów z zakresu historii literatury ukraińskiej. Działalność polityczna Franki, a także konserwatyzm władz krajowych oraz sprzeciw niektórych profesorów przeszkodziły mu jednak w objęciu posady. Powtórna próba osadzenia Franki na uniwersytecie w roku 1907, po śmierci Antoniego Kaliny, też się nie powiodła (prawdopodobnie z powodu zaostrzenia w tym roku stosunków polsko-ukraińskich na uniwersytecie). Franko pozostał w świadomości społecznej „wielkim nieobecnym” filologiem uniwersyteckim.

Docentem, a w latach 1898-1918 profesorem ruskiego (ukraińskiego) języka i literatury został Ołeksandr Kołessa (1867-1945), habilitowany w 1895 roku na uniwersytecie w Czerniowcach ${ }^{21}$. Postrzegano go jako specjalistę z zakresu folklorystyki, historii języka ukraińskiego (zwłaszcza XV-wiecznego), historii literatury ukraińskiej i polsko-ukraińskich powiązań literackich. Był on także politykiem Ukraińskiej Partii Narodowo-Demokratycznej (Українська Національно-Демократична Партія), a jednocześnie autorem radykalnej pieśni rewolucyjnej Шалійте, шалійте скажені кати. Kołessa, poważny badacz, negocjował w Wiedniu, broniąc ukraińskich spraw na uniwersytecie. Po I wojnie światowej pozostał w Pradze, gdzie objął katedrę na Uniwersytecie Karola. Niesprawiedliwie uważano go za ,wygodnego władzy” konkurenta Franki. Zarzucano mu, że w swej pracy habilitacyjnej powiększył skalę wpływu Mickiewicza na twórczość Szewczenki, co miało mieć decydujące znaczenie przy jego wyborze na profesorskie stanowisko ${ }^{22}$. Oskarżenia te są niesprawiedliwe, o czym świadczą teksty Kołessy z pierwszej połowy XX wieku ${ }^{23}$ - napisane również na podstawie koncepcji Franki oraz w całości przesiąknięte ,ideą ukraińską" (jego tezą filologiczną jest słynne zdanie, że „powieść ukraińska oparta na życiu narodu zajmuje, jak nie pierwsze, to jedno z pierwszych miejsc w literaturze światowej") ${ }^{24}$.

Ważną figurą uniwersyteckiej ukrainistyki początku XX wieku stał się też Kyryło Studyńskyj (Кирило Студинський, Cyryl Studziński) ${ }^{25}$. Urodzony 4 października 1868 roku we wsi Kipiaczka w powiecie tarnopolskim, w rodzinie księdza greckokatolickiego, był wnukiem słynnego działacza ruskiego, księdza Stefana Kaczały ${ }^{26}$. Studiował na uniwersytetach lwowskim i wiedeńskim, między innymi pod kierun-

20 Спогади про Івана Франка, Львів 1997, s. 316.

21 В. Моторний, Олександр Колесса й украӥнсько-чеські взаємними міжвоєнного двадяциліття, „Проблеми слов'яновзнавства” 2002, Вип. 52, s. 110-117.

22 Спогади про Івана Франка..., s. 314.

23 О. Колесса, Погляд на історію украӥнської мови, Прага 1924.

24 Idem, Генеза української новітньої повісти, Прага 1927, s. 26.

25 У. Єдлінська, Кирило Студинський (1868-1941). Життєписно-бібліографічний нарис, Львів 2006; А. Кліш, Кирило Студинський: життя та діяльність, „Інтелігенція і влада” 2006, Вип. 6, s. 74-83.

26 Життєпис Кирила Студинського (1939), Особова справа професора Львівського університету Кирила Студинського, 1939 р., Архів Львівського національного університету імені Івана Франка, http://archive.lnu.edu.ua/osobova-sprava-kyryla-studynskoho-1868-1941 [dostęp: 11.08.2017]. 
kiem słynnego slawisty Vartoslava Jagića. W Wiedniu wykrystalizował się kierunek studiów naukowych Studyńskiego - historia literatury ukraińskiej. Po zdobyciu doktoratu w 1894 roku, krótko (do 1895 r.) prowadził badania naukowe w Sankt Petersburgu i Kijowie oraz pogłębiał studia pod kierownictwem Aleksandra Brücknera na Uniwersytecie Berlińskim. Początkowo pracował jako nauczyciel w lwowskich i krakowskich szkołach średnich, był też docentem Uniwersytetu Jagiellońskiego (1897-1899). W tym czasie rozpoczął bardzo intensywną pracę naukową, publikując między innymi Пересторога. Руський пам'ятник початку XVI віка. Літературно-історична студія (Львів, 1895) oraz artykuły poświęcone ruskim (pod względem językowym i kulturowym) utworom z XVI-XVII wieku. W latach 1900-1918 był najpierw docentem, a później profesorem uniwersytetu lwowskiego. W tym czasie drukował prace i materiały źródłowe poświęcone polemice religijnej XVI-XVII wieku ${ }^{27}$. Publikował w językach ukraińskim i polskim artykuły i monografie związane z literaturą ukraińską i „odrodzeniem galicyjskim” („галицьким відродженням”) XIX wieku, szczególnie z postaciami Szaszkiewicza i Hołowackiego ${ }^{28}$, oraz z folklorem „lirników”. W jego twórczości osobne miejsce zajmują dzieła poświęcone klasykom literatury Ukrainy Centralnej - Tarasowi Szewczence i Iwanowi Kotlarewskiemu. Oddzielnym nurtem zainteresowań Studyńskiego były tematy powiązane z polsko-ukraińskimi kontaktami literackimi (Польські консnірації серед руських питомиів і духовенства в Галичині в роках 1831-1848, Львів 1908). Jednocześnie Studyńskyj był posłem do Sejmu Galicyjskiego, jednym z kierowników ukraińskiej partii Chrześcijańsko-Społecznej (Християнсько-суспільна партия) oraz członkiem Rady Szkolnej Krajowej.

Po 1918 roku jego kariera uniwersytecka została przerwana. W wyniku wojny polsko-ukraińskiej o Lwów i Galicję został on internowany jako zwolennik Zachodnioukraińskiej Republiki Ludowej (ZURL). Nie złożył przysięgi na wierność państwu polskiemu, co było przyczyną niedopuszczenia go do stanowiska profesora. W latach 1923-1939 Kyryło Studyńskyj nie miał stałej pracy; pełnił różne funkcje administracyjne w ukraińskich instytucjach naukowych (m.in. jako przewodniczący Naukowego Towarzystwa im. T. Szewczenki we Lwowie w latach 1923-1932). Prowadził dalej intensywną pracę badawczą i był jedną z centralnych figur ukraińskiego życia kulturalnego Lwowa tego czasu. Ilarion Świencickyj tak o nim pisał: „Jako galicyjsko-ukraiński filolog wyszedł Kyryło Studyńskyj z deskryptywno-rejestracyjnej biobibliograficznej metody Omeliana Ogonowskiego i został przy analityczno-syntetycznej metodologii analizy materiału źródłowego, z której chętnie dobierał fragmenty kulturalno-narodowe"29. Równocześnie społeczeństwo ukraińskie i polskie

27 Zob. Пам'ятки полемічного письменства кін. XVI і поч. XVII віку, Львів 1906; Pierwszy występ literacki Hipacyusza Pocieja, Lwów 1902; Ze studiów nad literatura polemiczna, Lwów 1906.

28 Geneza poetycznych utworow Markiana Szaszkiewicza (1895, ukraiński przekład 1910); Кореспонденция Якова Головачького в лїтах 1835-49 (Львів 1909).

29 І. Свєнціцкий, Загальна характеристика наукової діяльности академіка Кирила Студинського, ЗНТШ, 1930, т. 49: Ювілений збірник на пошану акад. Кирила Студинського, Ч. 1: Праџі філологічні, s. 7. 
czasów międzywojennych postrzegało go jako sowietofila dążącego do zbliżenia z ZSSR i Ukrainą Sowiecką (został tam mianowany członkiem Akademii Nauk).

Mianowany na krótko przed I wojną światową (w 1913 r.) docentem slawistyki uniwersytetu lwowskiego (do 1931 r.) Ilarion (Hilarion) Świencickyj (Święcicki, Іларій Святицкій, Свєнціцкий, Свєнціцький) (1876-1956) był jeszcze jednym wybitnym ukrainistą lwowskim o skomplikowanej biografii naukowej i politycznej ${ }^{30}$. Urodzony 7 kwietnia 1876 roku w Busku ${ }^{31}$ Świencickyj (który demonstracyjnie pragnął zmienić „polskobrzmiące” nazwisko na rusko-ukraińskie Świjatyckyj) w 1899 roku podjął studia w Instytucie Archeologicznym i na uniwersytecie w Sankt Petersburgu. W 1902 roku tymczasowo został kustoszem biblioteki rusofilskiego Domu Narodowego (Narodnego) we Lwowie. Pierwotnie był slawistą skoncentrowanym na języku i kulturze rosyjskiej, ideologii panruskiej - znanym lwowskim specjalistą w tej dziedzinie. Jego podręczniki języka rosyjskiego, wydawane w latach 1903-1915 i wznowione w 1931 roku, utrzymane są w tonie sympatii dla Rosji i jej wpływów na cały obszar Europy Wschodniej. Kiedy jednak metropolita Andrej Szeptyckyj (Szeptycki) w 1905 roku zaprosił Świencickiego do objęcia stanowiska kustosza ukraińskiego Muzeum Narodowego (Національний Музей) we Lwowie, w poglądach uczonego zaszła zmiana. Nie zrywając całkowicie z rusycystyką ani ze środowiskiem rusofilskim, zwrócił się ku studiom średniowiecznej ukraińskiej literatury, języka oraz sztuki i folkloru. Podjął liczne i udane studia z zakresu historii języka ukraińskiego na tle indoeuropejskim oraz ogólnosłowiańskim ${ }^{32}$. Studenci odbierali wykłady Świencickiego entuzjastycznie: „Chociaż jego język polski nie był nadzwyczajny, to na jego wykłady uczęszczali także studenci różnych lwowskich szkół wyższych, a w dużej sali wykładowej panowała cisza kościelna. Każdy wykład kończyły burzliwe oklaski”33. Świencickyj próbował wplatać w dyskurs ukraiński podstawowe wiadomości o niezbyt popularnych w Galicji pisarzach rosyjskich (np. o Puszkinie). W tym sensie aż do 1939 roku pozostawał on między paradygmatami ideologicznymi, usiłując łączyć rusofilską i ukraińską inteligencję Lwowa.

30 Іларіон Семенович Свєниіцький (до 120-ліття від дня народження), уклад. Л. Пан ів, Львів 1996; Іларіон Свєниіџький. Біобібліографічний покажчик, ред. Л. Коць-Григорчук, 2 вид., Львів 2008; В. С. Александрович, Свєнціџький Іларіон Семенович [w:] Енциклопедія історії України: у 10 mm, т. 9, Київ 2012, s. 471.

31 Життєпис I. С. Свенціцького, ark. 4, Особова справа Іларіона Семеновича Свєнціцького, 1944-1956 pp., Архів Львівського національного університету імені Івана Франка, http://archive.lnu.edu.ua/osobova-sprava-ilariona-semenovycha-svjentsitskoho-1944-1956-rr-106-ark/ [dostęp 11.08.2017].

32 Нариси з істориї украӥнської мови (Львів 1920), podpisane „І. Свєнціцкий доцент університета у Львові"; słownik ukraińsko-polski i polsko-ukraiński (Словник украӥнсько-польський $i$ польсько- украӥнський, Львів 1920), podręcznik Rzecz о języku ukraińskim. Gramatyka z przyktadami (Lwów 1923), zbiór materiałów o krytycznym odbiorze twórczości Tarasa Szewczenki w XIX i XX w. (Шевченко в світлі критики й дійсности, Львів 1922), studia o tekstach Wołodymyra Wynnyczenki, historii literackiej i folklorystycznej motywów Bożego Narodzenia (Різдво Христове в поході віків, Львів 1933) сzу о obrazach Rusi i Połowców w ukraińskim piśmiennictwie (Русь і Половиі в староукраїнськім письменстві, Львів 1939).

33 В. Барагура, Як я став журналістом. Спогади зі студентських років 1928-34, Торонто, б.p.в, с. 23. 
Postacie Ołeksandra Kołessy, Kyryła Studyńskiego oraz Ilariona Świencickiego pokazują jeszcze jedną stronę ukrainistyki galicyjskiej pierwszej połowy XX wie$\mathrm{ku}$. Było to dążenie Ukraińców do utworzenia własnego uniwersytetu we Lwowie (lub depolonizacji istniejącego). Taka postawa okazała się sprzeczna z oczekiwaniami strony polskiej. Polacy bowiem postrzegali uniwersytet ukraiński w stolicy Galicji jako zagrożenie dla polskiego stanu posiadania w mieście i kraju. Dla Ukraińców własna uczelnia wyższa stanowiła symboliczne urzeczywistnienie ukraińskości Lwowa i Galicji, ale także możliwość realizacji naturalnego pragnienia zdobywania wyższego wykształcenia w języku ojczystym. Żądania ukrainizacji uniwersyteckich studiów wyrażały się w interpelacjach profesorów-polityków (O. Kołessy czy K. Studyńskiego) do władz państwowych, w walkach na korytarzach uczelni, w manifestacjach ulicznych, w gremialnych wystąpieniach studentów, którzy zapisywali się na inne uczelnie ( $w$ tym m.in. na Uniwersytet Jagielloński), a po I wojnie światowej w wezwaniu do bojkotu Uniwersytetu Jana Kazimierza. Jak skarżył się Studyńskyj w autobiografii z 1939 roku: „polskie władze chciały wyrzucić z uniwersytetu wszystkie katedry ukraińskie i przeprowadziły to systematycznie".

W 1921 roku powołano tajny Uniwersytet Ukraiński (Львівський (тає́мний) український університе́т), prześladowany przez władze państwowe ${ }^{34}$. Jego profesorowie (Kyryło Studyńskyj, Iwan Bryk, Jarosław Hordyńskyj, Ilarion Świencickyj, Filaret Kołessa, Anton Gęsiorski/Gensiorskyj, Spirydion Karchut, Mychajło Wozniak) prowadzili alternatywne wykłady filologii uniwersyteckiej. Obejmowały one: zarys historii języka ukraińskiego (Świencickyj), gramatykę języka staroukraińskiego (Bryk), zarys rozwoju ukraińskiego folkoru (Kołessa) i literatury ukraińskiej (Studyńskyj). Studenci nielegalnej ukrainistyki uczęszczali na wykłady i proseminaria $z$ historii dramaturgii ukraińskiej oraz metodologii literatury, słuchali wykładów $\mathrm{z}$ fonetyki oraz fizjologii dźwiękowej języka ukraińskiego ${ }^{35}$. Zagrożony przez naloty policji i narażony na ryzyko zamknięcia Ukraiński Tajny Uniwersytet nie istniał długo - zakończył działalność (według różnych autorów) w latach 1925-1926.

Po 1926 roku wykładowcy i słuchacze nielegalnej ukrainistyki lwowskiej byli zmuszeni do wyboru między instytucjami zagranicznymi i państwowymi. Poza uniwersytetem pozostał między innymi były profesor uniwersytetu w Czerniowcach, późniejszy wykładowca w Pradze Wasyl Simowycz, autor strukturalistyczno-funkcjonalistycznej pracy Практична граматика украӥнської мови (1918, wyd. 2 $1920)^{36}$. W Krakowie mieszkali i pracowali na UJ pisarz i specjalista od literatury ukraińskiej Bohdan Łepkyj (Łepki) oraz wybitny fonetysta-fonolog Iwan Ziłyński (Іва́н Зіли́нський), który na podstawie pracy Opis fonetyczny języka ukraińskiego habilitował się w 1931 roku na UJ. Kierował tam Seminarium Języków Ruskich

34 П. Хобзей, Таємний університет у Львові, „Україна: Наука і культура” 1991, Вип. 25, s. 45-59. Historię tego uniwersytetu skreślił ostatnio Marian Mudryj (Akademia militans..., s. 887-911).

35 В. Мудри й, Змагання за украӥнські університети у Львові, Львів-Нью-Йорк 1999, s. 88$89,107$.

36 Jego gramatyka była obowiązkowym podręcznikiem dla studenów Jana Janowa - zob. В. Барагура, op. cit., s. 37. 
Studium Słowiańskiego ${ }^{37}$. W Krakowie publikowały wyniki swoich badań także dialektolog Zofia Rabiejówna (Rabij) zajmująca się dialektem bojkowskim oraz Maria Przepiórska-Owczarenko badająca dialekt nadsański ${ }^{38}$. Studia ukrainistyczne we Lwowie i Krakowie stanowiły zatem część ukraińskiego życia kulturalnego obu miast $^{39}$. Lwowska ukrainistyka pozauniwersytecka była natomiast rozproszona między ukrainistykę gimnazjalną ${ }^{40}$ a studia realizowane przez Towarzystwo Naukowe im. Szewczenki, Instytut Stauropigijski we Lwowie ${ }^{41}$, czy nawet w Samborze (przy czasopiśmie „Litopys Bojkiwszczyny”, które łączyło m.in. filologów ze Lwowa i z Krakowa ${ }^{42}$ ).

Studia ukrainistyczne na uniwersytecie lwowskim w latach 1920-1930 skupiały się głównie wokół osoby Jana Janowa ${ }^{43}$. Urodzony 22 listopada 1888 roku w Moszkowcach w powiecie kałuskim, po ukończeniu seminarium nauczycielskiego oraz gimnazjum w Stanisławowie w 1909 roku został studentem slawistyki na uniwersytecie lwowskim oraz uczniem Wilhelma Bruchnalskiego i Adama Kryńskiego. W 1913 roku uzyskał doktorat z polonistyki na podstawie pracy Stowa powtarzajace języka polskiego. Następnie uzupełnił studia we Fryburgu. Podczas I wojny światowej jako rosyjski jeniec wojenny został przewieziony do Taszkentu, gdzie w latach 1918-1922 zajmował stanowisko docenta na miejscowym uniwersytecie oraz w Zakładzie Językoznawstwa Słowiańskiego Instytutu Orientalistycznego. W latach 1922-1925 pracował w archiwum uniwersytetu lwowskiego, a następnie został docentem katedry filologii słowiańskiej. W 1927 roku otrzymał stanowisko profesora nadzwyczajnego, a w 1936 roku profesora zwyczajnego katedry filologii ruskiej.

Głównym obiektem naukowych zainteresowań Janowa w zakresie ukrainistyki była dialektologia gwar południowozachodnich oraz historia języka ukraińskiego

37 I. Ziłyński, Opis fonetyczny języka ukraińskiego, Kraków 1932; idem, A Phonetic Description of the Ukrainian Language, Cambridge 1979.

38 Z. Rabiejówna, Dialekt Bojków, „Sprawozdania z Czynności i Posiedzeń PAU” 1932, t. 37; М. Пшепюрська-Овчаренко, Мова украӥнців Надсяння, ред. М. Лесів, Перемишль 2007.

39 М. Литв ин, Українське культурно-освітнє життя в Кракові (кінець XIX-перша третина ХХ століття) [w:] Украӥна: культурна спадщина, національна свідомість, державність, Вип. 16: Ювілейний збірник на пошану Івана Патера, Львів 2008, s. 245-251.

40 Wiele znakomitych studiów filologicznych (historycznoliterackich i językoznawczych) ogłoszali nauczyciele ukraińskich szkół średnich, a zwłaszcza Gimnazjum Akademickiego.

${ }_{41} \mathrm{O}$ tym środowisku zob.: I. Орлев ич, Ставропігійський інститут у Львові (кінець ХVIII ст-60mі рр. ХІХ ст.), Львів 2000; О. К и и и ч к, Львівський Ставропігійський інститут у громадському житті Галичини другої половини XIX-початку XX ст., Львів 2001.

42 Р. Голик, Книги, ідеї та стереотипи галицької провінції XX ст.: „Літопис Бойківщини” y міжвоєнному Самборі, „Записки Львівської національної наукової бібліотеки ім. В. Стефаника: зб. наук. Праць” 2009, Вип. 1(17), s. 223-248.

43 Я. Рігер, Ян Янів як дослідник гуиульських говірок [w:] Гуиульські говірки: Лінгвістичні та етнолінгвістичні дослідження, Львів 2000, s. 38-47; J. Rieger, Wstęp [w:] J. Janów, Stownik huculski, oprac. J. Rieg er, Kraków 2001, s. VII-XXIV; О. Купчинський, Ян Янів (Jапów) - польський дослідник української літератури та мови: (3 додатком бібліографії важливіших пращь з українознавства), „ЗНТШ. Праці філологічної секції” 2003, т. 246, s. 523-540. 
na tych terenach ${ }^{44}$. Szczególnie zajmował się ukraińskimi tekstami apokryficznymi jako pamiątkami języka i literatury. Swoje prace po II wojnie światowej kontynuował w Krakowie ${ }^{45}$. Jedno z głównych dzieł Janowa, Stownik huculski, opublikowano dopiero wiele lat po jego śmierci ${ }^{46}$. Janów jako polonista badał problemy historii i dialektologii języka oraz dziejów literatury polskiej, a także kontakty kulturowe i lingwistyczne polsko-ukraińskie. Opracowywał argotyzmy w mowie mieszkańców Galicji (Przyczynki do lafiryndy, 1932). Podkreślano, że jego studia z pogranicza dotyczące wzajemnych wpływów przynosiły znakomite rezultaty ${ }^{47}$. Jego zainteresowania badawcze wychodziły daleko poza slawistykę, w kierunku studiów orientalistycznych (w 1922 r. został sekretarzem Polskiego Towarzystwa Orientalistycznego) i komparatystycznych; w swoich pracach poruszał się między starohinduską a europejską spuścizną kulturalną i literacką. Uniwersalizm, ascetyzm naukowy i solidne w oczach słuchaczy podstawy metodologiczne wzmacniały autorytet profesora także w środowisku ukrainistycznym. Wołodymyr Barahura tak wspominał Janowa: „Znał język polski, ukraiński, rosyjski, niemiecki, litewski i sanskryt. [...] Korzystał z metodologii rosyjskiej szkoły slawistycznej, zawzięcie występował przeciwko półi pseudonaukowcom. Często powtarzał maksymę: »Prawdziwy naukowiec nie dba o dobro materialne «" 48 .

Studenci ukraińscy uniwersytetu lwowskiego postrzegali Jana Janowa w różny sposób: jako Polaka zaangażowanego w problemy ukraińskie, jako przedstawiciela rodziny mieszanej polsko-ukraińskiej lub wprost jako spolonizowanego Ukraińca Iwana Janiwa (podobnie postrzegali innego wybitnego lingwistę Jerzego Kuryłowicza, który jednak przyznawał się wyłącznie do narodowości polskiej). Darzono go sympatią, między innymi za posługiwanie się językiem ukraińskim nie tylko na wykładach, ale także podczas spotkań towarzyskich. Przyjmowane to było jako świadectwo podwójnej identyfikacji narodowej. Stepan Szach, nauczyciel lwowskich szkół średnich, a potem dyrektor gimnazjum ukraińskiego w Przemyślu, pisał: „Początkowo uważaliśmy go za Ukraińca lub za »perekińczyka « ${ }^{49}$, tym bardziej że on wyśmienicie mówił po ukraińsku, a w gronie nauczycielskim rozmawiał wyłącznie po ukraińsku. Lecz był on Polakiem, chłopskim synem [...]; rodzice jego byli rzymskimi katolikami, ale w ich wsi i domu językiem potocznym był ukraiński" ${ }^{50}$. Za przejaw pozytywnego nastawienia Janowa wobec słuchaczy ukraińskich uważano także to, że - podobnie jak etnograf badający życie okolicznych Rusinów Adam Fischer - miał

44 Zob. Gwara matoruska Moszkowiec i Siwki Naddniestrzańskiej z uwzględnieniem wsi okolicznych (1926); Z fonetyki gwar huculskich (1928); Język ruski w ewangeliarzu kaznodziejskim z Trościańca (1930); Wplyw stownictwa rumuńskiego na Podkarpaciu (1938).

45 Legendarno-apokryficzne opowieści ruskie o męce Chrystusa z uwzględnieniem zabytków staropolskich (1931); Apokryf o dwunastu piatkach (1934).

46 J. Janów, Stownik huculski, oprac. J. Rieger, Krakow 2001.

47 J. Handel, Dzieje językoznawstwa, Lwow 1935, s. 257.

48 В. Барагура, op. cit., s. 19.

49 „Perekińczyk” w gwarze lwowskiej oznacza zdrajcę.

50 С. Шах, Львів - місто моєї молодости. Цісарсько-королівска академічна гімназія, Львів 2010, s. 134. 
Ukraińców wśród asystentów (Josifa Szemleja oraz Teoktysta Paczowskiego) i „z radością fotografował się ze studentami ukraińskimi" ${ }^{51}$.

Ukrainistyczne projekty Janowa realizowali także jego młodzi współpracownicy $^{52}$. Wśród nich był dialektolog Stefan Hrabec (1912-1972), który analizował gwary huculskie i doktoryzował się w 1939 roku na podstawie pracy Nazwy geograficzne Huculszczyzny (gotowej do druku w tym samym roku we Lwowie, ale wydanej dopiero w 1950 r. w Krakowie) $)^{53}$. Do pomocników Janowa należał również Władysław Kuraszkiewicz (1905-1997), znany dzięki swojej pracy o języku ruskim doby halicko-wołyńskiej ${ }^{54}$. Warto pamiętać też o badaniach językoznawczych kierownika katedry filologii słowiańskiej Zdzisława Stiebera (1903-1980) nad gwarami łemkowskimi z lat 1934-1936 oraz (z udziałem Stefana Hrabeca) z lat 1937-1938 - nad gwarami bojkowskimi. Stały się one podstawą do wydania wielkiego lingwistycznego atlasu Łemkowszczyzny (Atlas językowy dawnej Łemkowszczyzny, 1956-1964, 8 zeszytów) oraz projektu atlasu gwar bojkowskich (z 1934 r.) (5. $^{55}$ Podobne zainteresowania miał także uczeń Henryka Karola Gaertnera, Karol Dejna (1911-2004), późniejszy profesor Uniwersytetu Łódzkiego. Z prac ukrainoznawczych Dejny można wymienić Podolsko-wotyńskie pogranicze językowe (1938) czy Gwary ukraińskie Tarnopolszczyzny (1957). W ten sposób obok tradycyjnej „ukrainistyki ukraińskiej” wyrosła w dwudziestoleciu międzywojennym ukrainistyka polska, związana z lwowskim i krakowskim środowiskiem naukowym.

Wykłady Janowa obejmowały dialektologię wschodniosłowiańską, gramatykę języka małoruskiego (ukraińskiego), literaturę apokryficzną oraz praktyczną lekturę staro-cerkiewno-słowiańskich tekstów i latopisu Nestora ${ }^{56}$. Studenci narzekali na zbyt akademicki styl wykładów Janowa, odbierając go jako pedantycznego pedagoga „starej daty":

Monotonnym cichym głosem czytał swe solidnie opracowane wykłady. Na seminariach trudno było zrozumieć, o co mu chodzi, bo tak był drobiazgowy. U niego trzeba było być na wszystkich zajęciach seminaryjnych, napisać prace seminaryjne i złożyć egzaminy z deskryptywnej, historycznej i porównawczej gramatyki języka ukraińskiego oraz z dawnej i nowszej literatury ukraińskiej [...]. Kandydatów na magistrów nowszej literatury zobowiązywał do precyzyjnego zaznajomienia się z pracami Zerowa Нове украӥнське письменство і До джерел ${ }^{57}$.

Wrzesień 1939 roku położył kres dotychczasowym strukturom uniwersyteckim we Lwowie. W warunkach radzieckiej ukrainizacji Lwowa oraz jego instytucji

51 В. Барагура, op. cit., s. 27.

52 В. Грещук, Дослідження гуиульських говірок у Львівському університеті міжвоєнного пеpioдy, „Етнос і культура” 2011-2012, № 8-9, s. 99-103.

53 S. Hrabec, Nazwy geograficzne Huculszczyzny, Kraków 1950.

${ }_{54}$ W. Kuraszkiewicz, Gramoty Halicko-Wolyńskie XIV-XV wieku. Studium językowe z zasitkiem funduszu kultury narodowej (Prace Polskiego Towarzystwa dla badań Europy Wschodniej i Bliskiego Wschodu, nr 7), Kraków 1934.

55 Atlas gwar bojkowskich, red. J. Rigier (t. 1-7, Wrocław 1980-1991). Zob. też: J. Rieger, Polskie atlasy gwar ukrainskich, „Діалектологіні студії”, 6: Лінгвістичний атлас - від створення до інтерпретаиіï, Львів 2006, s. 9-15.

${ }_{56}$ С. Шаx, op. cit., s. 134-135.

57 В. Барагура, op. cit., s. 19. 
państwowych Uniwersytet Jana Kazimierza został przemianowany na Uniwersytet Iwana Franki, a studia ukrainistyczne (obok rusycystyki) stały się głównym kierunkiem wykładów i badań slawistycznych. Do uczelni powrócił Kyryło Studyńskyj (pełniący obowiązki prorektora, a jednoczenie deputowany do parlamentu). Zatrudnieni zostali wybitni językoznawcy: Wasyl Simowycz (1880-1944), który w 1941 roku pełnił funkcję rektora, oraz specjalista od historii literatury ukraińskiej Mychajło Wozniak. Ukrainizacja uniwersytetu w latach 1939-1941 okazała się jednak prowizoryczna, a nawet tragiczna w skutkach dla niektórych uczonych. Z początkiem wojny niemiecko-radzieckiej uniwersytet zamknięto, a Studyńskyj, który jeszcze niedawno zdawał się faworyzowany przez reżim stalinowski, w czerwcu 1941 roku został ewakuowany do Kijowa i rozstrzelany przez NKWD. Czas niemieckiej okupacji wydawał się okresem straconym - uczelnia przestała funkcjonować, a wykładowcy musieli znaleźć sobie inną pracę. Część filologów, między innymi Jan Janów, musiała się zmierzyć z trudnymi warunkami materialnymi. Barahura wspominał: „Uniwersytet był zamknięty i profesor pracował w bibliotece Towarzystwa Naukowego Szewczenki. Mówiliśmy do siebie w dwóch językach: on do mnie po ukraińsku, ja do niego po polsku. Skarżył się, że bieduje, i my, jego byli studenci, odwiedzaliśmy go czasem w jego domu i przynosiliśmy wiktuały"s8.

Po 1944 roku Uniwersytet Iwana Franki i cały Lwów zmieniły swe etniczne oraz społeczne oblicze. Polscy profesorowie zostali wysiedleni do Polski, część naukowców ukraińskich emigrowała lub była represjonowana przez władze radzieckie. Tylko nieliczni z przedwojennych wykładowców uniwersyteckich, jak Ilarion Świencickyj czy Teoktyst Paczowski, pozostali na uczelni i nawet rozwijali swoją karierę (Świencickyj kierował katedrą filologii słowiańskiej). Janów po wojnie pracował w Krakowie, a Kołessa nadal działał w Pradze. Tradycje lwowskiej filologii zostały przerwane, naukowe środowiska rozproszone, a ich przedstawiciele zmuszeni do adaptacji w tak zwanym progresywnym socjalistycznym społeczeństwie.

W przeciągu prawie stu lat ukrainistyka na uniwersytecie lwowskim przeszła długą ewolucję. Stanowiła część slawistyki galicyjskiej ${ }^{59}$. Oficjalny początek uniwersyteckiej ukrainistyki we Lwowie w 1848 roku był rezultatem zarówno spontanicznego rozwinięcia badań nad językiem, kulturą i literaturą ruską (ukraińską) w chwili politycznego odrodzenia narodowego, jak i reakcji władz austriackich na galicyjską Wiosnę Ludów. Przedstawiciele pierwszych dwóch pokoleń ukrainistów lwowskich (Hołowacki i Ogonowski) należeli do stanu duchownego, stąd liczne powiązania studiów filologicznych z teologicznymi. Następne generacje reprezentowane były już przez profesorów świeckich, co wynikało z zsekularyzowania inteligencji ukraińskiej. Ewolucja ideologiczna oraz naukowo-intelektualna lwowskiej ukrainistyki uniwersyteckiej okazała się jednak bardziej złożona. Przed I wojną światową widoczne było przejście od idei staroruskich i rusofilskich do ukrainofilskiej. Po 1918 roku studia ukrainistyczne stały się raczej politycznie neutralne. Na płaszczyźnie

58 Ibidem, s. 21.

59 Р.Гол ик, Формуваннягалицької славістики в контексті наукових теорій та етнокультурних стереотипів (XIX-30-ті роки XX ст.), „Проблеми слов'янознавства” 2011, Вип. 60, s. 21-32. 
intelektualnej lwowska filologia ukraińska zmieniła pierwotny (post)romantyczny charakter na pozytywistyczny, w którym widać wpływy zarówno młodogramatykow zachodnich, jak i wschodnich (rosyjskich) uczonych. W pierwszej połowie XX wie$\mathrm{ku}$ pozostawała ona raczej tradycjonalistyczna, zorientowana na wzorce badawcze z przełomu wieków. Brakowało jej nowatorskiej postaci tego typu, co strukturalista Wasyl Simowycz, a tym bardziej jednostek tak wybitnych jak lingwista Jerzy Kuryłowicz lub filozof Roman Ingarden po stronie polskiej. To skutkowało stopniowym zmarginalizowaniem studiów ukrainistycznych $\mathrm{w}$ miarę polonizacji uniwersytetu lwowskiego. A przecież już u swoich początków ukrainistyka nie była kierunkiem faworyzowanym; potem została zdominowana przez polonistykę, traktowaną jako kamień węgielny slawistyki lwowskiej. Na jej modus vivendi wpłynęła walka toczona w Galicji będącej Piemontem jednocześnie polskim i ukraińskim, ze Lwowem stanowiącym jej centrum. Po wojnie polsko-ukraińskiej walka ideologiczna stała się bardziej napięta, a centrum ukrainistyki lwowskiej częściowo mieściło się poza granicami ówczesnej Polski (Uniwersytet Karola w Pradze), a częściowo przeniosło się do ukraińskich instytucji społecznych (od nielegalnego Ukraińskiego Uniwersytetu do legalnego Towarzystwa Naukowego Szewczenki), gdzie prowadzono badania. Mimo to studia ukrainistyczne na uczelni wciąż istniały. Historia filologii ukraińskiej we Lwowie jest zatem częścią dziejów polsko-ukraińskich - historią „tolerancji wewnątrz konfrontacji”. Przyłączenie Lwowa i Galicji (Małopolski) Wschodniej do Ukrainy Radzieckiej w 1939 roku, ich ostateczna inkorporacja w 1944 roku i przesiedlenie polskiej ludności Lwowa po II wojnie światowej zasadniczo zmieniły sytuację. Od tego czasu to właśnie ukrainistyka (obok rusycystyki) stała się fundamentem studiów humanistycznych na uniwersytecie lwowskim. Była to formalnie ta sama, ale w zasadzie zupełnie inna ukrainistyka, funkcjonująca w odmiennych warunkach społecznych, demograficznych, kulturalnych i naukowych.

\section{BIBLIOGRAFIA}

\section{Źródła}

Atlas gwar bojkowskich, red. J. Rigier (t. 1-7, Wrocław 1980-1991).

Hrabec S., Nazwy geograficzne Huculszczyzny, Kraków 1950.

Janów J., Gwara małoruska Moszkowiec i Siwki Naddniestrzańskiej z uwzględnieniem wsi okolicznych, Lwów 1926.

Janów J., Stownik huculski, oprac. J. Rieger, Kraków 2001.

Janów J., Uwagi o gwarach huculskich i śladach ich stosunków z polszczyzna oraz o pierwotnej ludności Ziemi Czerwieńskiej, „Sprawozdania Towarzystwa Naukowego we Lwowie" 1928, vol. 8, z. 2, s. 51-59.

Janów J., Z deklinacji małoruskiej (Celownik, narzednik i miejscownik liczby mnogiej), „Prace Filologiczne” 1926, t. 10, s. 337-356. 
Janów J., Z fonetyki gwar huculskich [w:] Symbolae grammaticae in honorem Ioannis Rozwadowski, vol. 2, Warszawa 1928, s. 259-290.

Kuraszkiewicz W., Gramoty Halicko-Wotyńskie XIV-XV wieku. Studium językowe z zasitkiem funduszu kultury narodowej (Prace Polskiego Towarzystwa dla badań Europy Wschodniej i Bliskiego Wschodu, nr 7), Kraków 1934.

Ogonowski E., O przyimkach w języku starosłowiańskim, ruskim i polskim, „Rozprawy i Sprawozdania z Posiedzeń Wydziału Filologicznego Akademii Umiejętności” 1877, t. V, s. 17-222.

Ogonowski E., O ważniejszych wtaściwościach języka ruskiego, „Rozprawy i Sprawozdania z Posiedzeń Wydziału Filologicznego Akademii Umiejętności” 1884, t. 10, s. 30-93.

Rabiejówna Z., Dialekt Bojków, „Sprawozdania z Czynności i Posiedzeń PAU” 1932, t. 37. Rieger J., Polskie atlasy gwar ukraińskich, „Діалектологіні студіï”, 6: Лінгвістичний атлас-від створення до інтерпретації, Львів 2006, s. 9-15.

Zilyn'skyj I., A Phonetic Description of the Ukrainian Language, Cambridge 1979.

Ziłyński I., Opis fonetyczny języka ukraińskiego, Kraków 1932.

Барагура В., Як я став журналістом. Спогади зі студентських років 1928-34, Торонто, б.р.в.

Життєпис Кирила Студинського (1939), Особова справа професора Львівського університету Кирила Студинського, 1939 р., Архів Львівського національного університету імені Івана Франка, http://archive.lnu.edu.ua/osobova-sprava-kyrylastudynskoho-1868-1941 [dostęp: 11.08.2017].

Життєпис I. С. Свенціцького, ark. 4, Особова справа Іларіона Семеновича Свєнціцького, 1944-1956 pр., Архів Львівського національного університету імені Івана Франка, http://archive.lnu.edu.ua/osobova-sprava-ilariona-semenovycha-svjentsitskoho1944-1956-rr-106-ark/ [dostęp: 11.08.2017].

Іван Франко. Документи і матеріали. 1856-1965, Київ 1966.

Колесса О., Генеза украӥнської новітньої повісти, Прага 1927.

Колесса О., Погляд на історію украӥнської мови, Прага 1924.

Огоновскій О., Исторія литературы рускои, Часть I-IV, Львів 1889.

Пшепюрська-Овчаренко М., Мова украйнців Надсяння, ред. М. Лесів, Перемишль 2007.

Спогади про Івана Франка, Львів 1997.

Шах С., Львів - місто моєї молодости. Цісарсько-королівска академічна гімназія, Львів 2010.

\section{Literatura}

Akademia militans. Uniwersytet Jana Kazimierza we Lwowie, red. A. Redzik, Kraków 2015. Encyclopedia. Львівський національний університет імені Івана Франка, 2 т., Львів 2011.

Finkel L., Starzyński S., Historia Uniwersytetu Lwowskiego, Lwów 1894.

Handel J., Dzieje językoznawstwa, Lwów 1935.

Kozik J., Między reakcja a rewolucją: studia z dziejów ukraińskiego ruchu narodowego w Galicji w latach 1848-1849, Kraków 1975.

Kozik J., Ukraiński ruch narodowy w Galicji w latach 1830-1848, Kraków 1973. 
Mokry W., Ruska Trójca. Karta z dziejów życia literackiego Ukraińców w Galicji w pierwszej połowie XIX wieku, Kraków 1997.

Osadczy W., Święta Ruś. Rozwój i oddziaływanie idei prawosławia w Galicji, Lublin 2007.

Rieger J., Polskie atlasy gwar ukraińskich [w:] Діалектологічні студіï, 6: Лінгвістичний атлас - від створення до інтерпретаиіï, Львів 2006, s. 7-36.

Rieger J., Wstęp [w:] J. Janów, Słownik huculski, oprac. J. Rieger, Kraków 2001, s. VIIXXIV.

Universitati Leopoliensi. Trecentesimum quinquagesimum anniversarium suae fundationis celebranti. In memoriam. Uniwersytetowi Lwowskiemu dla upamiętnienia trzysta pięćdziesiątej rocznicy jego fundacji. Materiały sesji zorganizowanej w dniach 14-15 stycznia 2011 w Krakowie przez Uniwersytet Jagielloński, Wyższa Szkołę Filozoficzno-Pedagogiczna „Ignatianum” w Krakowie, Uniwersytet Papieski Jana Pawła II w Krakowie, Polską Akademię Umiejętności, Kraków 2011.

Александрович В.С., Свєнціицкий Іларіон Семенович [w:] Енц̧иклопедія історії України: у 10 mm, т. 9, Київ 2012.

Голик Р., Книги, ідеї та стереотипи галицької провінції ХХ ст.: ,, Літопис Бойківщчини” y міжвоснному Самборі, „Записки Львівської національної наукової бібліотеки ім. В. Стефаника: зб. наук. Праць” 2009, Вип. 1(17), s. 223-248.

Голик Р., Формування галицької славістики в контексті наукових теорій та етнокультурних стереотипів (XIX-30-ті роки XX cm.), „Проблеми слов'янознавства” 2011, Вип. 60, s. 21-32.

Голик P., Alma Mater Leopolitana: Львівський університет в уявленнях галицької інтелігенції XIX-XX cm., „Вісник Львівського університету. Серія історична” 2013, Вип. 49, s. 78-92.

Грещук В., Дослідження гуиульських говірок у Львівському університеті міжвоєнного періоду, „Етнос і культура” 2011-2012, № 8-9, s. 99-103.

Єдлінська У., Кирило Студинський (1868-1941). Життеписно-бібліографічний нарис, Львів 2006.

Єдлінська У., Мовознавство в житті й творчості Іларіона Свєнціцького [w:] Діалектологічні студіi, 1: Мова в часі і просторі, Львів 2003, s. 160-170.

Іларіон Свєнціиький. Біобібліографічний покажчик, уклад. Л. Панів, Львів 2008.

Іларіон Семенович Свєнціиький (до 120-ліття від дня народження), уклад. Л. Панів, Львів 1996.

Кокорудз I., Професор др. Омелян Огоновский. Огляд єго житя і наукової та літературної діяльности, „Записки Наукового товариства імені Шевченка” 1895, т. 5, s. $1-34$.

Киричук О., Львівський Ставропігійський інститут у громадському жстті Галичини другої половини XIX-початку XX ст., Львів 2001.

Колб Н., ,З $З$ Богом за Церкву і вітчизну”: греко-католицьке парафіяльне духовенство в Галичині в 90-х роках ХІХ століття, Жовква 2014.

Купчинський О., .Ян Янів (Janów) - польський дослідник української літератури та мови: (3 додатком бібліографії важливіших праць з українознавства), „Записки Наукового товариства імені Шевченка. Праці філологічної секції” 2003, т. 246, s. 523-540.

Кліш А., Кирило Студинський: життя та діяльність, „Інтелігенція і влада” 2006, Вип. 6, s. 74-83. 
Литвин М., Украӥнське культурно-освітнє життя в Кракові (кінецьь XIX-перша третина ХХ століття) [w:] Украӥна: культурна спадщина, національна свідомість, державність, Вип. 16: Ювілейний збірник на пошану Івана Патера, Львів 2008, s. $245-251$.

Микитюк В., Іван Франко та Омелян Огоновський: мовчання і діалог, Львів 2000.

Мозер М., Причинки до історії української мови, Харків 2008.

Моторний В., Олександр Колесса й українсько-чеські взаємними міжвоєнного двадяциліття, „Проблеми слов'яновзнавства” 2002, Вип. 52, s. 110-117.

Мудрий В., Змагання за українські університети у Львові, Львів-Нью-Йорк 1999.

Орлевич I., Ставропігійський інститут у Львові (кінецьь XVIII cm-60-ті pp. XIX cm.), Львів 2000.

Пашук В., Огоновський Омелян Михайлович [w:] Енциклопедія історії Украӥни у 10 $m m$, т. 7, Київ 2010, s. 523.

Рігер Я., Ян Янів як дослідник гуцульських говірок [w:] Гуцульські говірки: Лінгвістичні та етнолінгвістичні дослідження, Львів 2000, s. 38-47.

Свєнціцкий I., Загальна характеристика наукової діяльности академіка Кирила Студинського, „Записки Наукового Товариства ім. Шевченка” 1930, т. 99: Ювілений збірник на пошану акад. Кирила Студинського, Ч. 1: Праці філологічні.

Седляр А.В., Яков Головацикий и поступление российских изданий в Галицию (18481867 г2.) [w:] Берковские чтения. Книжная культура в контексте международных контактов: материаль Междунар. науч. конф., Минск, 16-17 мая 2013 г., ред. Н.Ю. Березкина, В. И. Васильев, Минск 2013, s. 337-340.

Седляр О., Важливі епізоди історії книговидання галицьких русинів 40-50-х років ХІХ cm. (видавнича діяльність Якова Головацького) [w:] Studia o książe i informacji, red. M. Komza, Wrocław 2014, nr 33 (Acta Universitatis Wratislaviensis, nr 3653), s. $61-75$.

Седляр О., Хрестоматія руської літератури Якова Головаџького як інформаційний та освітній проект: плани та їх реалізація, „Вісник Львівського університету. Серія книгознавство, бібліотекознавство та інформаційні технології” 2012, Вип. 7, s. $19-53$.

Сухий О., Львівський університет на рубежі ХІХ-XX ст.: організація, иколи, громадське життя, „Вісник Львівського університету. Серія історична” 2013, Випуск 49, s. 52-77.

Франко І., Професор Омелян Огоновський [w:] I. Франко, Зібрання творів: у 50 m., т. 43, Київ 1986.

Хобзей Н., 3 історії львівської діалектологї [w:] Діалектологічні студії, 4: Школи, постаті, проблеми, Львів 2004, s. 63-72.

Хобзей П., Таємний університет у Львові, „Україна: Наука і культура” 1991, Вип. 25, s. $45-59$. 